\title{
A randomized controlled trial on lactoferrin versus ferrous sulphate for the treatment of mild to moderate iron deficiency anaemia in pregnancy
}

\author{
Swati Gawai*, Michelle Fonseca, Deepali Kapote
}

Department of Obstetrics and Gynecology, LTMMC and Sion Hospital Mumbai, Maharashtra, India

Received: 29 September 2019

Revised: 27 December 2019

Accepted: 02 January 2020

\section{*Correspondence:}

Dr. Swati Gawai,

E-mail: gawai.swati@gmail.com

Copyright: () the author(s), publisher and licensee Medip Academy. This is an open-access article distributed under the terms of the Creative Commons Attribution Non-Commercial License, which permits unrestricted non-commercial use, distribution, and reproduction in any medium, provided the original work is properly cited.

\begin{abstract}
Background: One of the important factors associated with maternal and foetal complications during pregnancy is Anaemia. Various oral preparations of iron are available, and each has different bioavailability, efficacy and adverse effects. Lactoferrin is a naturally existing iron-binding multifunctional glycoprotein, and a member of a transferrin family, thus belonging to those proteins capable of binding and transferring iron. Lactoferrin has considerably less gastrointestinal side effects than ferrous sulfate and is very useful as well as promising alternative to ferrous sulphate. Methods: Prospective randomized controlled study. Total 100 females with 24 to 36 weeks of pregnancy with haemoglobin between 8 to 10 grams were included out of which 50 patients were given ferrous sulphate $200 \mathrm{mg}$ BD and 50 patients were given lactoferrin $250 \mathrm{mg}$ BD daily for 8 weeks. Various haematological parameters and the adverse effects of both the drugs were studied at registration, 4 weeks and 8 weeks and compared.

Results: Thus, after this study authors can say that the rise in haemoglobin with lactoferrin was $1.58 \mathrm{~g} / \mathrm{dl}$ while with ferrous sulphate it was $1.67 \mathrm{~g} / \mathrm{dl}$ at 8 weeks. Adverse effects were much lesser in Group A taking lactoferrin compared to Group B.

Conclusions: Thus, lactoferrin has the advantage over ferrous sulphate in having less side effects and increasing the compliance and thus the efficacy of the drug compared to ferrous sulphate.
\end{abstract}

Keywords: Anaemia, Ferrous sulphate, Haemoglobin, Iron deficiency anaemia, Lactoferrin, Pregnancy, Serum Iron, Total iron binding capacity

\section{INTRODUCTION}

Anemia has a significant impact on the health of the fetus as well as that of the mother. ${ }^{1,2}$ Many preparations are available to increase haemoglobin. ${ }^{3}$ Lactoferrin is an oral preparation which is easily accepted by the patients. ${ }^{4,5}$ Very few studies about this are done in India. Hence, authors decided to study and compare ferrous sulphate and lactoferrin in pregnant females. Objective of this study was to compare the effectiveness and adverse effects of lactoferrin versus ferrous sulphate for the treatment of mild to moderate Iron deficiency anaemia during pregnancy.

\section{METHODS}

Prospective randomized controlled Study was done for a period of 8 weeks from December 2018 to February 2019.

Total 100 females with 24 to 36 weeks of pregnancy with haemoglobin between 8 to 10 grams were included out of 
which 50 patients were given ferrous sulphate $200 \mathrm{mg}$ $\mathrm{BD}$ and 50 patients were given lactoferrin $250 \mathrm{mg} \mathrm{BD}$ daily for 8 weeks. Various haematological parameters like rise in haemoglobin, rise in serum iron, rise in serum ferritin, fall in TIBC and the adverse effects of both the drugs were studied at registration, 4 weeks and 8 weeks and compared. And authors found that all these indices were almost same in both the groups and the overall acceptability of ferrous sulphate was less, around $22 \%$ while of lactoferrin was $96 \%$.

\section{Inclusion criteria}

- Pregnant women from 24-36 weeks of gestation

- $\quad$ Mild to moderate anemia.

\section{Exclusion criteria}

- Women with a history of anemia due to any other causes other than IDA

- Severe anemia requiring blood transfusion

- History of peptic ulcer

- Known hypersensitivity to iron preparations.

\section{RESULTS}

It was found in our study that in group A the mean haemoglobin at registration was 9.03 which increased to 9.77 at 4 weeks and 10.61 at 8 weeks. Thus, total rise in haemoglobin was $1.5 \pm 0.49$ grams. P-value was significant (Table 1).

Table 1: Group A: rise in haemoglobin with lactoferrin $(\mathbf{n}=\mathbf{5 0})$.

\begin{tabular}{|llll|}
\hline & At registration & At 4 weeks & At 8 weeks \\
\hline Mean & 9.03 & 9.77 & 10.61 \\
\hline SD & 0.55 & 0.56 & 0.46 \\
\hline
\end{tabular}

$\mathrm{F}$-value $=108.52$ and $\mathrm{P}$-value $<0.05$.

In Group B, the mean haemoglobin at registration was 9.13 which increased to 9.88 at 4 weeks and 10.80 at 8 weeks. Thus, total rise in haemoglobin was $1.67 \pm 0.44$ grams. P-value was significant (Table 2).

Table 2: Group B: rise in haemoglobin (g/dl) with ferrous sulphate $(n=50)$.

\begin{tabular}{|llll|} 
& At registration & At 4 weeks & At 8 weeks \\
\hline Mean & 9.13 & 9.88 & 10.80 \\
\hline SD & 0.58 & 0.50 & 0.41 \\
\hline
\end{tabular}

$\mathrm{F}$-value $=141.87$ and $\mathrm{P}$-value $<0.05$.

Table 3: Group A: rise in serum iron (mcg/dl) with lactoferrin $(\mathbf{n}=\mathbf{5 0})$.

\begin{tabular}{|llll|} 
& At registration & At 4 weeks & At 8 weeks \\
\hline Mean & 39.83 & 60.6 & 79.73 \\
\hline SD & 5.92 & 7.53 & 7.07 \\
\hline
\end{tabular}

$\mathrm{F}$-value $=413.03, \mathrm{P}$-value $<0.05$.
When serum iron was studied, it was found that at registration the value was 39.83 which rose to 60.6 at 4 weeks and 79.73 AT 8 weeks. The total rise in serum iron was found to be 39.90. P-value was significant (Table 3).

Table 4: Group B: rise in serum iron $(\mathrm{mcg} / \mathrm{dl})$ with ferrous sulphate $(n=50)$.

\begin{tabular}{|lll|l|}
\hline & At registration & At 4 weeks & At 8 weeks \\
\hline Mean & 40.08 & 60.25 & 77.29 \\
\hline SD & 4.61 & 4.96 & 5.37 \\
\hline
\end{tabular}

F-value $=710.735, \mathrm{P}$-value $<0.05$.

In Group B it was found that at registration the value was 40.08 which rose to 60.25 at 4 weeks and 77.29 at 8 weeks. The total rise in serum iron was found to be 37.21. $\mathrm{P}$-value was significant (Table 4).

Table 5: Group A: rise in serum ferritin (mcg/dl) with lactoferrin $(\mathbf{n}=\mathbf{5 0})$.

\begin{tabular}{|lll|l|}
\hline & At registration & At 4 weeks & At 8 weeks \\
\hline Mean & 9.37 & 11.25 & 13.16 \\
\hline SD & 0.87 & 0.93 & 1.04 \\
\hline
\end{tabular}

F-value $=195.27, \mathrm{P}$-value $<0.05$.

In Group A, serum ferritin was 9.37 at registration, 11.25 at 4 weeks and 13.16 at 8 weeks. The total rise was found to be 3.79 which was significant and proven by $\mathrm{P}$-value (Table 5).

Table 6: Group B: rise in serum ferritin $(\mathrm{mcg} / \mathrm{dl})$ with ferrous sulphate $(n=50)$.

\begin{tabular}{|lll|l|}
\hline & At registration & At 4 weeks & At 8 weeks \\
\hline Mean & 9.49 & 11.64 & 13.63 \\
\hline SD & 0.84 & 0.86 & 0.87 \\
\hline
\end{tabular}

F-value $=297.859$, P-value $<0.05$.

In Group B, serum ferritin was 9.49 at registration, 11.64 at 4 weeks and 13.63 at 8 weeks. The total rise was found to be 4.14 which was significant and proven by $\mathrm{P}$-value (Table 6).

In Group A, TIBC was 407.31 at the registration which decreased to 382.04 at 4 weeks and 348.12 at 8 weeks.

Table 7: A Group A: fall in TIBC (mcg/dl) with lactoferrin $(\mathbf{n}=\mathbf{5 0})$.

\begin{tabular}{|lll|l|}
\hline & At registration & At 4 weeks & At 8 weeks \\
\hline Mean & 407.31 & 382.04 & 348.12 \\
\hline SD & 36.15 & 31.44 & 25.01 \\
\hline
\end{tabular}

F-value $=9.90, \mathrm{P}$-value $<0.05$.

Total fall in TIBC was 59.19. P-value was significant (Table 7).

In Group B, TIBC was 421.62 at the registration which decreased to 382.92 at 4 weeks and 345.45 at 8 weeks. 
Total fall in TIBC was 76.17. P-value was significant (Table 8).

\section{Table 8: Group B: fall in TIBC (mcg/dl) with ferrous sulphate $(\mathbf{n}=\mathbf{5 0})$.}

\begin{tabular}{|llll|} 
& At registration & At 4 weeks & At 8 weeks \\
\hline Mean & 421.62 & 382.92 & 345.45 \\
\hline SD & 32.46 & 29.90 & 27.01 \\
\hline
\end{tabular}

F-value $=82.90, \mathrm{P}$-value $<0.05$.

Thus, on comparing the adverse effects of both the drugs, constipation was seen in $92 \%$ of pregnant females taking ferrous sulphate while those taking lactoferrin only $14 \%$ had constipation. Next more common adverse effect was darkening of stool which was seen in $90 \%$ of population taking ferrous sulphate while it was not seen with lactoferrin at all i.e. Zero percent. gastric up set was seen in $84 \%$ of population on ferrous sulphate and $30 \%$ in women with lactoferrin. Vomiting was seen in $62 \%$ with ferrous sulphate and $18 \%$ with lactoferrin. Abdominal pain was seen in $24 \%$ of women having ferrous sulphate and $10 \%$ of women taking lactoferrin.

Table 9: Adverse effects.

\begin{tabular}{|lll|}
\hline & $\begin{array}{l}\text { Lactoferrin } \\
\text { (Group A) } \\
\mathbf{N = 5 0}\end{array}$ & $\begin{array}{l}\text { Ferrous sulphate } \\
\text { (Group B) } \\
\mathbf{n = 5 0}\end{array}$ \\
\hline Gastric upset & 15 & 42 \\
\hline Acceptability & 48 & 11 \\
\hline Vomiting & 9 & 31 \\
\hline Constipation & 7 & 46 \\
\hline Dark stools & 0 & 45 \\
\hline Abdominal pain & 5 & 12 \\
\hline
\end{tabular}

The overall acceptability of ferrous sulphate was less, around $22 \%$ while of lactoferrin was $96 \%$ (Table 9).

Thus, lactoferrin has the advantage over ferrous sulphate in having less side effects and increasing the compliance and thus the efficacy of the drug compared to ferrous sulphate.

\section{DISCUSSION}

One of the important factors associated with maternal and foetal complications during pregnancy is Anaemia. ${ }^{1,2}$ The World Health Organization (WHO) defines anaemia in pregnant women as $\mathrm{Hb}<11.0 \mathrm{~g} / \mathrm{L}$.

Anemia has a significant impact on the health of the fetus as well as that of the mother. ${ }^{1,2}$ Anemia is common pregnancy due to increased demand of iron for the growing fetus and placenta; and increased red blood cell mass (with expanded maternal blood volume in the third trimester), which is further aggravated with other factors such as childbearing at an early age, repeated pregnancies, short intervals between pregnancies and poor access to antenatal care and supplementation. ${ }^{3}$
It impairs the oxygen delivery through the placenta to the fetus and interferes with the normal intrauterine growth, leading to fetal loss and perinatal deaths4. Anemia is associated with increased preterm labor preeclampsia and maternal sepsis.

Iron deficiency anaemia (IDA) is the most common cause of anaemia in pregnancy. ${ }^{1,5,6}$ IDA develops when available iron is insufficient to support normal red cell production. The daily requirement of iron is around 1.5 $\mathrm{mg}$ in nonpregnant women. This requirement increases dramatically during pregnancy to reach 6-7 mg/day (total $1000 \mathrm{mg}$ ) with advanced gestational age. ${ }^{7}$ Pregnancy causes a twofold to threefold increase in the requirement for iron and a 10- to 20-fold increase in folate requirement. The increase in demand for iron is mainly due to fetal requirement, placenta, blood volume, tissue accretion, and the intra-partum potential for blood loss 4 . Iron absorption takes place in the apical site of proximal duodenum through its reduction by duodenal cytochrome $B$ followed by trans-cellular trafficking via divalent metal transporter I, and its storage into ferritin. Iron efflux occurs in basolateral sites via Ferroportin, the only known cellular iron exporter from tissues into blood, has been found in enterocytes, hepathocytes, placental cells and macrophages. Another pivotal component of systemic iron homeostasis is hepcidin, a circulating peptide hormone synthesized by hepatocytes in iron loading conditions and secreted in plasma and urine. The binding of hepcidin with ferroportin resulting in ferroportin phosphorylation, internalization and degradation in lysosomes, hinders iron export. Iron homeostasis disorders appear to arise from hepcidin and/or ferroportin dysregulation. Dietary changes are not sufficient to correct iron deficiency in pregnancy. Oral iron supplements are still considered as the first choice, with a therapeutic dose of 100 to $200 \mathrm{mg}$ elemental iron daily. Management of iron deficiency anemia with ingestion of iron medications will allow the hemoglobin levels to increase in a slow pattern, around after 1-2 weeks of therapy, will eventually increase roughly $2 \mathrm{~g} / \mathrm{dL}$ The $\mathrm{Hb}$ concentration should increase by around $20 \mathrm{~g} / \mathrm{L}$ over 3 to 4 weeks and iron should be continued for 3 months after the $\mathrm{Hb}$ returns to normal (and at least 6 weeks postpartum) to replenish iron stores. ${ }^{4}$ Many women are intolerant to oral iron because of gastric irritation and diarrhoea or constipation. ${ }^{2}$ If a reduction in oral iron dose is not effective, then treatment with parenteral iron is required. Lactoferrin forms a very good and promising alternative to oral iron preparations and help in avoiding parenteral iron and associated complications. In pregnant women, oral administration of bovine lactoferrin, 30\% iron saturated, significantly improved hematological parameters, including number of red blood cells, hemoglobin, total serum iron, serum ferritin concentrations with lesser adverse effects compared to those observed in pregnant women treated with ferrous sulfate Lactoferrin (formerly known as lactotransferrin) is a glycoprotein, and a member of a transferrin family, thus belonging to those proteins 
capable of binding and transferring iron. ${ }^{4,5}$ Lactoferrin is a naturally existing iron-binding multifunctional protein; it is present at high concentrations in human milk and in the milk of other mammals. ${ }^{5}$ It is also present in other body fluids such as tears, saliva, bile, pancreatic juice, genital and nasal secretions as well as in circulating neutrophils. ${ }^{5}$ Therefore, oral administration of bovine lactoferrin as an iron-supplying molecule is an appealing therapeutic strategy. The molecular composition of lactoferrin is composed of a single polypeptide chain which is folded into two lobes ( $\mathrm{N}$ and $\mathrm{C}$ lobes). ${ }^{5}$ Both lobes are connected by a $\alpha$-helical residue, making Lactoferrin a structurally flexible molecule in character.

Lactoferrin could sustain binding of iron in variable $\mathrm{pH}$ array. Specific receptors mediate and influence the physiological action, by directly altering the cell membrane, by competitive mode of absorption for the iron ions or via its enzymatic action. ${ }^{8}$ Its molecular and physiological behavior and features are augmented by its capability of sustaining the iron binding feature at low $\mathrm{pH}$. The raised haematological values by lactoferrin is related to decreased serum interleukin 6and increased hepcidin detected as prohepcidin whereas ferrous sulphate has raised interlukin 69. Data and results of research studies display and reveal that bovine lactoferrin has considerably less gastrointestinal side effects than ferrous sulfate (Table 9). ${ }^{2}$ The rise in RBC cellular mass is associated by a rise in maternal physiological requirements and demand of iron by an additional 500 $\mathrm{mg}$ during gestation and additional $300 \mathrm{mg}$ transferred to the developing fetus and $200 \mathrm{mg}$ that are necessary for physiologically normal daily iron loss, making total iron demands in total gestational period is about $1 \mathrm{~g}^{7}$

In our study which was done for 2 months duration from $11^{\text {th }}$ December 2018 to $11^{\text {th }}$ February 2019 total of 100 patients were included and 2 groups of 50 in each group were formed randomly. One group was given ferrous sulphate $200 \mathrm{mg}$ bd and other group was given lactoferrin $250 \mathrm{mg}$ bd and various haematological parameters were studied in each group at 4 weeks and 8 weeks respectively. In our study authors found that the rise in haemoglobin with lactoferrin was $1.58 \mathrm{~g} / \mathrm{dl}$ (Table 1) while with ferrous sulphate it was $1.67 \mathrm{~g} / \mathrm{dl}$ (Table 2) at 8 weeks. In serum iron the total rise by lactoferrin is 39.90 $\mathrm{mcg} / \mathrm{dl}$ (Table 3) while with ferrous sulphate it is 37.21 $\mathrm{mcg} / \mathrm{dl}$ (Table 4). Rise of serum ferritin was $3.79 \mathrm{mcg} / \mathrm{dl}$ (Table 5) at 8 weeks with lactoferrin while it was 4.14 $\mathrm{mcg} / \mathrm{dl}$ (Table 6) with ferrous sulphate. The fall in TIBC with lactoferrin and ferrous sulhphate are $59.19 \mathrm{mcg} / \mathrm{dl}$ (Table 7) and $76.17 \mathrm{mcg} / \mathrm{dl}$ (Table 8).

Thus, authors can very well conclude that lactoferrin is more effective and safer alternative to oral iron preparations and should be advised in pregnant females with iron deficiency anaemia as it will increase the compliance due to minimal adverse effects as compared to ferrous sulphate. ${ }^{9,10}$

\section{CONCLUSION}

Ferrous sulphate and Lactoferrin both are efficient in management of iron deficiency anemia in pregnancy. Lactoferrin displayed an excellent safety profile and improved compliance compared to ferrous sulphate with comparable efficacy. Thus, after this study authors can say that the rise in haemoglobin with lactoferrin was 1.58 $\mathrm{g} / \mathrm{dl}$ (Table 1) while with ferrous sulphate it was $1.67 \mathrm{~g} / \mathrm{dl}$ (Table 2) at 8 weeks. In serum iron the total rise by lactoferrin is $39.90 \mathrm{mcg} / \mathrm{dl}$ (Table 3) while with ferrous sulphate it is $37.21 \mathrm{mcg} / \mathrm{dl}$ (Table 4). Rise of serum ferritin was $3.79 \mathrm{mcg} / \mathrm{dl}$ (Table 5) at 8 weeks with lactoferrin while it was $4.14 \mathrm{mcg} / \mathrm{dl}$ (Table 6) with ferrous sulphate. The fall in TIBC with lactoferrin and ferrous sulhphate are $59.19 \mathrm{mcg} / \mathrm{dl}$ (Table 7) and 76.17 $\mathrm{mcg} / \mathrm{dl}$ (Table 8) respectively. Adverse effects were much lesser in Group A taking lactoferrin compared to Group B (Table 9). Most of the adverse effects were gastric upset, constipation, nausea, vomiting, darkening of stools etc. which were more associated with ferrous sulphate compared to lactoferrin (Table 9). Thus, it can be said that though the haematological parameters are showing slightly more improvement amongst Group B having ferrous sulphate but the difference is not much and the adverse effects with lactoferrin are negligible as compared to ferrous sulphate. Hence, compliance was better with lactoferrin. The acceptability of lactoferrin is more in pregnancy due to less gastric effects making it preferred drug in pregnancy compared to ferrous sulphate (Table 9).

Funding: No funding sources

Conflict of interest: None declared

Ethical approval: The study was approved by the Institutional Ethics Committee

\section{REFERENCES}

1. Rezk M, Dawood R, Abo-Elnasr M, Halaby AA, Marawan H. Lactoferrin versus ferrous sulphate for the treatment of iron deficiency anaemia during pregnancy: a randomized clinical trial. J Matern Fetal Neonatal Med. 2015:1-4.

2. Nappi C, Tommaselli GA, Morra I, Massaro M, Formisano C, Carlo CD. Department of Gynecology and Obstetrics, University of Naples" Federico II", Naples Italy Efficacy and tolerability of oral bovine lactoferrin compared to ferrous sulfate in pregnant women with iron deficiency anaemia: a prospective controlled randomized study. Acta Obstetricia et Gynecologica. 2009:88:1031-5.

3. Rezk M, Kandil M, Dawood R, Shaheen AE, Allam A. Oral lactoferrin versus ferrous sulphate and ferrous fumarate for the treatment of iron deficiency anaemia during pregnancy. J Adv Nutrit Human Metabol. 2015;2:e740.

4. Paesano R, Pacifici E, Benedetti S, Berlutti F, Frioni A, Polimeni A, et al. Safety and efficacy of lactoferrin versus ferrous sulphate in curing iron 
deficiency and iron deficiency anaemia in hereditary thrombophilia pregnant women: an interventional study. Biometals. 2014;27(5):999-1006.

5. Hemeda HM, Mohamed AAK, Islam BA, Hasan A, Ewies A. Effectiveness of bovine lactoferrin versus ferrous fumarate in the management of iron deficiency anemia in pregnancy: randomized clinical trial. Int J Repro Med Gynecol. 2018;4(1):006-011.

6. Paesano R, Torcia F, Berlutti F, Pacifici E, Ebano V, Moscarini M, et al. Oral administration of lactoferrin increases hemoglobin and total serum iron in pregnant women. Biochem Cell Biol. 2006;84:37780 .

7. Bothwell TH. Iron requirements in pregnancy and strategies to meet them. Am J Clin Nutr. 2000;72:257-64.

8. De Domenico I, Ward MD, Kaplan I. Regulation of iron acquisition and storage: consequences for iron- linked disorders. Nat Rev Mol Cell Biol. 2008;9:7281.

9. Donovan A, Lima CA, Pinkus JL, Pinkus GS, Zon LI, Robine $\mathrm{S}$, et al. The iron exporter ferroportin/Slc40a1 is essential for iron homeostasis. Cell Metabolism. 2005;1(3):191-200.

10. Nemeth E, Ganz T. Hepcidin and iron-loading anemias. Hematol J. 2006;91:727-32.

Cite this article as: Gawai S, Fonseca M, Kapote D. A randomized controlled trial on lactoferrin versus ferrous sulphate for the treatment of mild to moderate iron deficiency anaemia in pregnancy. Int $\mathrm{J}$ Reprod Contracept Obstet Gynecol 2020;9:562-6. 